\title{
Engaging in and Coping with Bribery by the Bodaboda Riders in Kisii town, Kenya
}

\author{
Joseph Ouma Oindo \\ Tangaza University College, Kenya \\ DOI: https://dx.doi.org/10.47772/IJRISS.2021.5323
}

\begin{abstract}
This survey was done under the context of the researcher's experience of an encounter with Kisii County askaris/traffic marshalls demanding a bribe from the researcher in order to be allowed to proceed to the Kisii town's Central Business District (CBD) while on a motorcycle. This background, therefore, provides the researcher with the motivation to explore how bodaboda/motorcycle riders in Kisii town engage in and cope with bribery. The study utilized exploratory research design while taking Grounded Theory approach to extract data from 100 bodaboda riders in Kisii town. By means of thematic analysis the findings showed that bribery is common among bodaboda riders and bribery amount is moderated not by the respondents' demographic characteristics - educational level, marital status, gender - but by social interaction or ethnicity which determines whether a rider belongs to the inner circle or outer circle.
\end{abstract}

Key Words: Corruption, Bribery, Bodaboda riders, Askaris, Ethnic Affiliation, Insider, Outsider

\section{INTRODUCTION}

$\mathrm{T}$ The use of motorcycles as a preferred means of public transport has been significantly attributed to the fact that it offers certain transport advantages in the form of easy manoeuvrability, ability to travel on poor roads, and demand responsiveness. As a result, motorcycle transport has become one of the most affordable types of transport in various parts of the world (Luchidio, Kahuthia \& Gatebe, 2013; Porter, 2014).

In the 1960s bicycle taxis were used to take people and their luggage between Uganda's border posts with Kenya, Tanzania and Rwanda (because they took people from - Border to Border they became known as -Bodabodas). Their use gradually spread throughout Uganda, Tanzania, Rwanda and Kenya. During the 1990s riders started to use motorbikes instead of bicycles, and the name - Bodaboda was used for them too.

In Kenya, currently the bodaboda transport system has spread to other parts of the country and is a common mode of transport across the country. The bodaboda transport sector is currently dominated by a majority of youthful population whose academic qualifications ranges from primary, secondary and university levels.

However, worldwide transport systems have always been riddled with allegations of corruption in the form of bribery running into millions of dollars. For Transparency International (2018), corruption avenues in the traffic sector involves payment of bribes where drivers give cash to traffic officers. The sectors most affected include the public motor vehicle transport system. Although, the motorcycle transport system gained prominence from the 1990s, it has not received much research as far as payment of bribery is concerned. It is against this backdrop that this present study sought to explore the possibilities of giving in to corruption and even coping with corruption in the form of bribes by the bodaboda riders against the county traffic marshalls, commonly known in Kenya as the county askaris.

\section{Background}

Martin and Schinzinger (2005) define bribery as "a substantial amount of money or goods offered beyond a stated business contract with the aim of winning an advantage in gaining or keeping the contract, and where the advantage is unfair or otherwise unethical," (Martin \& Schinzinger 2005; p. 159). For Remer (2017), bribery is an issue that permeates virtually every level of the society, ranging from individual, interpersonal interactions to international business deals to major government policy decisions.

A study done by Matsushima and Yamada (2016) in Vietnam showed positive correlations between the prevalence of bribery and health outcomes, and between the prevalence of bribery and health insurance coverage. The estimation results suggested that a higher prevalence of bribery correlates with a higher death rate, a higher infant mortality rate, and a lower health insurance coverage rate. When the prevalence of bribery increases by one percent, it increases the death rate by 0.009 per cent. Moreover, a higher prevalence of bribery correlates significantly with a higher infant mortality rate; when the prevalence of bribery increases by one percent, the infant mortality rate increases by over 0.03 per 1,000 live births.

Another study done by Hummel (2018) in Bolivian street markets showed that many Bolivians engage in corruption through intermediaries, like civil society representatives and lawyers, instead of bribing officials directly. The study further showed that civil society actors like street vendors' union representatives advance their careers by collecting and delivering bribes to specific bureaucrats. Collusive relationships between bureaucrats and intermediaries hide and perpetuate corruption, while giving the appearance of a transparent government that is responsive to civil society.

In a study to determine bribery practices in Sub-Saharan Africa, Pelizzo, Araral, Pak and Wu Xun (2016) found out 
that $7.85 \%$ of the firms operating in Southern Africa reported having paid bribes while the percentage of self-reported bribepaying firms is $9.79 \%$ in Eastern Africa, $17.81 \%$ in Western Africa and $37.87 \%$ in Central Africa. Evidence showed that firms are asked to pay bribes for a variety of purposesobtaining licenses and permits, dealing with tax inspections, getting the access to utilities (water, electricity, telephone), and securing government contracts. In fact, more than 20 percent of the African firms included in the sample reported that they need to pay bribes to get government contracts.

In Kenya, bribery dominates various sectors of both public and private institutions. From the perspective of land sector, high profile cases involving land governance problems have been thrust into the public domain. These include the case involving the grabbing of a playground belonging to Lang'ata Road Primary School in Nairobi and the tussle over a 134 acre piece of land in Karen. Land ownership and use have been a great source of conflict among communities and even families in Kenya, a situation exacerbated by corruption. The lands sector has consistently ranked as one of the most bribery prone sectors in Kenya coming in at number two in the East African Bribery Index 2014 with a score of 55 on an aggregate index of 0 to 100 , with a score of 100 being the worst score (Kempe, 2014).

In a study by the Transparency International (2017), majority of the respondents interacting with the Police $(68.8 \%)$ and Land Services $(55.1 \%)$ were asked (implicitly and explicitly) or offered to pay a bribe to access the services they were seeking followed by $48 \%$ and $45 \%$ interacting with the Judiciary and Civil Registration respectively. The least likelihood was recorded at Tax Services and Huduma Centers as $18.4 \%$ and $12.6 \%$ of respondents reported being asked (implicitly and explicitly) or offered to pay a bribe.

A study done by Van den Berg \& Noorderhaven (2016) in Lamu to explore users' perspectives on corruption in the hospitality sector showed that a condition of legal uncertainty, a lack of trust in institutions and negative ethnicity are the main dimensions that lead to prevalent bribery in Lamu. In terms of negative ethnicity, the study found out that service providers prefer to solicit bribes from those whom they term 'outsiders', i.e., those who are not the original inhabitants of the area or those who are of different ethnic communities. However, for those outside of this inner circle the choice to be corrupt is very risky: it may open the door to more pressure and extortion. The dominant coping strategy for these 'outsiders' therefore seems to be to 'sit it out': stay within the law, refuse to pay bribes, and accept that things will probably be slowed down considerably.

In a study done by Transparency International (2018), corruption avenues in the traffic sector involves payment of bribes where drivers give cash to traffic officers. In the study, $55 \%$ of the long distance drivers indicated that they had been asked to pay a bribe by the police while $20 \%$ were asked to pay for a bribe by traffic marshalls. Twenty five of the matatu SACCO respondents indicated that they had been asked to pay a bribe by the police while $34 \%$ mentioned traffic marshalls. Thirty six percent of Bodaboda riders indicated that they had been asked to pay a bribe by the police with another $21 \%$ stating that they had been asked by traffic marshalls. Thirty three percent of the taxi drivers said that they had been asked to pay for a bribe by the police. The Transparency International's study was carried out in Nairobi City County and also attempted to capture experiences of surrounding counties, namely; Kiambu, Machakos and Kajiado, while this present study centred on Bodaboda riders in Kisii town only.

\section{Objective of the Study}

1. To explore how bodaboda riders in Kisii town engage in and cope with bribery on the hands of county askaris.

\section{THEORETICAL FRAMEWORK}

In order to explore how bodaboda riders in Kisii town, Kenya engage in and cope with bribery on the hands of county askaris, this study used Grounded Theory approach. Grounded Theory (GT) was developed in the 1960s by the US sociologists Barney Glaser and Anselm Strauss with the objective of offering a formalized research program that emphasized openness and unbiasedness towards the empirical phenomenon. GT focuses on interpersonal relationships and the actions of individuals in groups and larger social settings. Due to its micro-sociological perspective, it has been applied in a variety of disciplines and in interdisciplinary research. However, its application in the study of bribery involving bodaboda riders is seldom recognized worldwide and in Kenya in particular. Therefore, this present study sought to bridge this gap.

Three elements are considered constitutive of the GT methodology. First, building of concepts instead of description: The principle task of GT is the analytical step from data to concepts. It is assumed that any data segment, for example, an interview statement, points to broader underlying ideas. Relevant data segments are therefore considered empirical indicators of theoretical concepts (Strauss 1987). Concepts are developed through constant comparison, interpretation, and abstraction of data segments, and they eventually form the building blocks of an empirically grounded theory.

Second, theoretical sampling and theoretical saturation: When GT is used, data collection and analysis is iterative, meaning that a first round of data collection is followed by data analysis and a subsequent round of data collection based on the initial findings. This procedure leads to the theoretical sampling of interviews and contributes to the theoretical saturation of the concepts. Third, writing of memos throughout the whole research process: GT requires that the decisions regarding case selection, sampling, and analysis that are taken repeatedly throughout the research process be documented in memos. 
Based on these characteristics, GT has been identified as the most suitable approach for this present study for one reason: The study aims to contribute "theoretically grounded" concepts to the existing theoretical body, with the objective of developing empirically grounded middle-range theories relating to how the bodaboda riders engage in and cope with corruption in Kisii town.

GT has numerous advantages, among them, being able to encourage the researcher to move through a process of discovery whereby themes and interpretations naturally emerge from the data. In essence, GT allows the researcher to derive meaning from the data and analysis using creative, inductive processes; it allows for the emergence of original findings from the data (Hussein, Hirst, Salyers \& Osuji, 2014).

Another notable advantage of the GT method is in its capacity to enable researchers collect rich data (Charmaz, 2006). In order to obtain rich data, researchers are expected to seek thick descriptions (Geertz, 1973) through writing "extensive field notes of observation" (Charmaz, 2006, p. 14), gathering thorough narratives from interviews, and above all "collecting respondents' written personal accounts" (p. 14). GT therefore enables the researcher to generate insight into the participants' world. It is the rich data that reveals what lies beneath the surface in any social setting.

GT, on the other hand, has limitations and one of its notable limitations is being an exhaustive process. Myers (2009) embraced the notion that researchers can become exhausted at the coding level with GT, as open coding is a time consuming, tiring and laborious process. The process of abstracting and encompassing concepts is not an easy task. Novice researchers may become so hindered and absorbed with the coding process that they may lose sight of accomplishing the task of discovering the ideas and themes that emerge from the data. Annells (1996) forewarned researchers who are planning to use GT that this approach is "not simple" (p. 177) and must not "be hurried" (p. 177), as it may take months to fine tune the theory around the core category. Annells (1996) further advised that a mentor should be available to help novice grounded theorists in their journey of inquiry. To respond to this limitation, the present researcher took three months to analyse data after initial collection under the guidance of an experienced researcher in GT.

Second, GT has been seen to harbour a high potential for methodological error. Charmaz (1989) contended that novice researchers using GT may tend to blur methodological lines by selecting purposeful instead of theoretical sampling. She further suggested that it is acceptable to start with purposeful sampling, however, the researcher must revert to theoretical sampling where the "process of data collection is controlled by the emerging theory" (Glaser, 1978, p. 36). Failure to do so will result in a lack of conceptual depth (Benoliel, 1996). The present researcher began data collection through simple random sampling and reverted to theoretical sampling after the first analysis.
Another pitfall the new researcher might face is the use of only one source of data, such as that of interviews. To help circumvent the utilization of one data source, Glaser (1978) recommended undertaking both observations and interviews as part of the data collection process. If a researcher ignores this advice it may cause him or her to focus on the lived experience of the subjects instead of the social process (Benoliel, 1996). In order to respond to this limitation, the present researcher used self-administered questionnaires, face to face interviews, participant observation and focus group discussions.

In terms of empirical research application, GT has received wide application in various fields including education, political sciences, anthropology, information technology and medicine. Wallace (2017) used GT to understand the factors leading to college students' spiritual development at a secular institution. The study also examined students' perceptions to determine the factors that facilitated their individual personal growth. GT data suggested that for students to experience growth in their spiritual identity, they must undergo a trigger disrupting their normal thinking patterns.

Ciby \& Raya (2014) used GT to explore victims' experiences of workplace bullying. The victims experienced various negative emotions as the initial reaction to bullying behaviours. As the bullying prolonged, the participants experienced various personal and work-related consequences. The self-coping mechanisms identified in the study were sharing emotional experiences with friends and family, having an easy-going attitude, voicing the issues, and perceived organizational support.

Similarly, Milosavljevic, Goluza, Keep, \& Ponta (2015) used GT to explore how the New South Wales public-hospitals' dietitians feel about their workplace. Data analysis revealed that dietitians sought validation of their work experience from five sources within the workplace which were: acquisition of knowledge; relationships with others; work culture; role clarity; and personal attributes.

In the field of information technology, Gandomani1\& Nafchi (2016) used GT to explore the challenges and problems that software companies are facing during Agile transition with the participation of 49 Agile experts from 13 different countries. In the field of business communication, Johnson \& Sohi (2016) also used GT to explore how companies deal with contractual breaches by their customers when legal enforcement is not a viable option. Based on in-depth interviews with 40 supplier managers and executives in multiple industries, the authors identified: (a) types of out-of contract alternatives for resolving breaches, (b) factors that lead to use of enforcement options outside the terms specified in the contract, (c) contextual influences, and (d) individual and firm-level consequences of outside-of contract enforcement (Johnson \& Sohi, 2016).

In medical sciences, Chilton \& Pires-Yfantouda (2015) used GT to understand adolescent type 1 diabetes self-management 
as an adaptive process. The findings illustrated how selfmanagement can be understood in terms of a continuum-based framework, ranging from difficulties with, to successful selfmanagement. Adaptation within the continuum can further be understood by specific transitional phases and process mechanisms, providing further depth to individuals' experiences of adaptation. The investigation provided a conceptual understanding of the complex issues adolescents encounter while adapting to and integrating a diabetes selfmanagement regime into their lives.

In ethnographic studies and counselling psychology, Mohd \& Bond (2013) used GT to explore cultural values and attitudes towards guidance and counselling services in one secondary school in Malaysia. Through the use of semi-structured individual interviews, group interviews and observations, data analysis indicated that there were different attitudes among the three groups of participants concerning counselling services and highlighted the role of a school system in elucidating attitudes towards guidance and counselling services.

Similarly, Fayyaz \& Kamal (2017) used GT to explore psychosocial factors related to practicing Hijab among Muslim women in Pakistan. The analysis revealed three core categories, namely, religious commitment, environmental adjustment and psychological satisfaction. These three factors appeared as the causal conditions which lead to wearing hijab.

Tong, Ng, Lee, Lee, Ismail, Khoo \& Abdullah (2018) also used GT to explore decision making process and factors contributing to research participation among General Practitioners (GP) in Malaysia. Results showed that the GPs' decision to participate in research was attributed to their inner drive and appreciation for primary care research and their confidence in managing their social and research environments.

In the African context, GT was used by Feldacker, Pintye, Jacob, Chung, Middleton, Iliffe, \& Kim (2017) to study continuing professional development for medical, nursing, and midwifery cadres in Malawi, Tanzania and South Africa. Fifty-two key informant interviews were conducted: 17 in Malawi, 19 in Tanzania and 16 in South Africa. The research revealed facility-level constraints, including poor infrastructure and weak supply chains, as restrictive to the implementation of continuous professional development of medical workers.

In Kenya, Riang'a, Nangulu, \& Broerse (2017) used GT to explore health beliefs concerning dietary practices among pregnant Kalenjin women in rural Uasin Gishu County. The study revealed that abstracted labour (big babies and lack of maternal strength), haemorrhage (low blood), or having other diseases and complications (evil or bad food) were the major perceived health threats that influence nutritional behaviour intention of the pregnant Kalenjin women in rural Uasin Gishu County. However, no known study in Kenya has utilized GT to explore bribery in the bodaboda industry, a gap that this present study sought to bridge.

\section{Research Context}

The survey was conducted in Kisii town, Kisii County. The main inhabitants in Kisii County are the Abagusii. The county shares common borders with Homabay and Migori counties to the West, Narok County to the South and Nyamira County to the North East. The administrative headquarter of the region is Kisii town. The county covers a total area of 1,317.5 square kilometres with an approximate population of $1,236,966$ (population and Housing census, 2009). Kisii County is mostly known for its association with soapstone majorly used in the production of curios. Agriculture is also another economic activity in the county, and the main crops grown are bananas, maize, tea and coffee. Animal farming is also practiced. Trade in the county is mainly on agricultural products (Nyabwengi, 2014). Notably, Kisii town is a home to vibrant boda boda transport sub-sector with majority of the youthful population involved in the boda boda business.

\section{RESEARCH METHODOLOGY}

This research survey was carried out in Kisii town. One hundred respondents, selected through simple random sampling, were reached. The study entirely used qualitative research process. In conducting the study, primary data was obtained through semi-structured indepth interviews, participant observations and focus group discussions. Some key respondents were also interviewed multiple times as the researcher's understanding of the phenomenon studied evolved to adapt and refine the questions over the course of the study in order to obtain a grounded theory.

\section{Data Analysis}

During the indepth interviews, notes were taken with the permission of the respondents. The data was initially coded in first-order terms which adhered faithfully to the words used by the respondents. Then there was a second round of data collection based on the initial findings. This procedure led to the theoretical sampling of interviews and contributed to the theoretical saturation of the concepts. The analysis was finished when theoretical saturation was considered to have been reached.

\section{Findings}

Majority of the boda boda riders interviewed were males $(97 \%)$ while female riders constituted (3\%). On age, $(58 \%)$ of the riders were in the age range of 26-33 years; with (30\%) falling within the 18-25 years age cohort; (10\%) were aged $34-41$ years; (2\%) were between $42-49$ years. On marital status, $(71 \%)$ of the riders were married, (29\%) were not married. On education, (23\%) had primary education; $(52 \%)$ had secondary; $(20 \%)$ had tertiary education and $(5 \%)$ had no education. However, the survey revealed that these demographic characteristics of the respondents did not 
influence their perception on engaging in and coping with bribery.

\section{Engaging in Bribery}

As far as engaging in bribery is concerned, majority of the respondents indicated that bribery among the bodaboda riders is a common phenomenon in Kisii town. Eighty percent of the respondents said that they had been asked to pay bribes by county askaris while $20 \%$ mentioned traffic police officers. A respondent gave an example when he began his bodaboda business in the town: "When the county askaris noticed that I was a new rider in town, they insisted that I should give them Sh.5000 so as to allow me operate in town."

Another form of corruption among the bodaboda riders is one respondent referred to as "bribing anonymous officers". In this form of bribery, it is not known who actually orders the bribes to be solicited, but the respondents argued that there are certain county officers who use ordinary citizens to solicit bribes from the bodaboda riders. Seventy three percent of the respondents argued that this is a rampant form of bribery in Kisii town. This finding is consistent with a study done by Hummel (2018) in Bolivian street markets which showed that many Bolivians engage in corruption through intermediaries, like civil society representatives and lawyers, instead of bribing officials directly.

The respondents further argued that failure to pay bribes leads to harassment and intimidation from the traffic marshalls. Harassment is used by county traffic marshalls to scare people into paying a bribe or to create incentives to pay a bribe to make the problem of harassment go away. According to one of the respondents, "They (traffic marshalls) will repeatedly ask riders for a bribe until they get it, or eventually back off until another day or week, which really hurts our businesses."

A respondent argued that he was threatened with a nonexistent regulation in the hope that he would pay a one-off fee of Ksh.15000 in order not to be fined for operating a bodaboda in Kisii town. The amount requested was for obtaining a non-existent motorcycle pass. For the respondents, this is a cash trap for the new bodaboda riders. The county askaris target new riders and solicit such money from them. Even if the riders later realize that they have been cheated, they have no mechanism to air their grievances.

Moreover, the respondents also unanimously said that county askaris have erected a sign post at the Kisii-Kilgoris junction next to Total Petrol Station indicating that bodaboda riders are not allowed to go beyond that point into Kisii CBD. However, all the respondents said the regulation is a cash-cow for the county askaris. There are two categories of bodaboda riders: there are those who are operating beyond that point into the CBD because they have paid good money to the askaris. However, those who have not paid 'good money' are not allowed into the CBD and often their motorcycles are towed away into a nearby county makeshift shade.
During the interviews, the respondents expressed distrust with both the national and local government agencies. This finding makes it difficult for the respondents to openly report cases of bribery due to fear of victimization. As a result, the respondents argued that the only way for them is to cope with bribery.

\section{Coping with Bribery}

At first glance the benefits to individual bribers seem to outweigh the potential threats. There is, however, a moderating factor that influences bribery: the social group one belongs to. In Kisii town, there are two distinct groups; those who belong to an inner circle and those who do not. A situation that is quite similar to the findings of the study by Van den Berg \& Noorderhaven (2016) in Lamu which explored users' perspectives on corruption in the hospitality sector.

The bodaboda riders within the inner circle experience more benefits and at the same time suffer fewer threats. This inner group consists of bodaboda riders who are predominantly local Abagusii people and close relatives and friends of the county askaris. But the respondents also revealed that through gifts and close social interaction one might also become part of the inner circle but this will take a long time because the county askaris must ascertain that this rider cannot leak the information regarding bribery incidences to external authorities such as the Ethics and Anti-Corruption Commission (EACC).

Entrance into the inner circle network is not easy. If you come from the outside you need to pay good money and win the trust of the county askaris. The answers from our respondents suggest the boundaries of the inner circle are basically defined through nepotism, favouritism, and tribalism. The most influential factor seems to be tribalism. Tribalism describes the phenomenon where members of a tribe are more loyal to their own tribe than to any other social group or category. Tribalism provides a powerful structure of social relations which enables trust and commitment between fellow tribesmen. This commitment in turn provides protection and enables one to reap better benefits and to be exposed to fewer threats. As per the findings of this survey, tribalism is a powerful moderator variable in bribery incidences among the bodaboda riders in Kisii town.

But, for the non-Abagusii bodaboda riders to enter into the inner circle and reap its benefits of majorly lower bribes, they must try to make friends and connections with the county askaris and with fellow riders from the community. This method takes a long time and is considered the least effective since it does not provide the same protection.

From thematic analysis of the responses, the second way of coping with bribery is to choose the corrupt option, and by bribing one gets rid of harassment from the county askaris. Sixty-five percent of the respondents indicated that this has been an option for them. However, they argued that it really 
affects their daily earnings but they have no choice except to choose the corrupt option. For the respondents, the only way of succeeding in the bodaboda business is bribing, if you do not bribe you cannot succeed.

A third approach is to ignore the demands of the county askaris and try to maintain business as normal, without either confronting corruption or indulging in it. However, the respondents said this is a risky option as it is open to intimidation and harassment. According to respondent R, it is not a viable option "because it exposes one to arbitrary arrests by the county askaris even if one has done nothing wrong". However, the respondents argued that this option is commonly taken by those who do not want to risk getting caught or who do not want to be caught up in any corrupt scheme. The possibility of employing this coping strategy relies heavily on having everything in order. Having everything in order involves having all the required licences, insurances, helmets, reflectors and operating only within the county approved regions. Only $28 \%$ of the respondents opt for this third approach as they have complied with the regulations. It is predominantly an option for those in the outer circle.

Lastly, there is the option of actively pursuing justice and upholding moral values, trying to fight bribery. This option involves whistle-blowing. This fighting option, according to $98 \%$ of the respondents is risky and one never wins for the reason that the county askaris "protect each other". Moreover, the respondents also argued that whistle-blowing has led to the mysterious disappearance of some bodaboda riders in the town and their bodies were later found dumped in thickets.

\section{DISCUSSION}

Results from the study have shown that bodaboda riders had a general agreement of the prevalence of bribery. Regardless of the respondents demographic characteristics, such as educational level, marital status and gender, the riders engage and cope with bribery in various forms. Surprisingly, despite the general consensus among bodaboda riders that insurance, licence and helmets easily lead one to adopt ignoring the county askaris' demand for bribes as a coping strategy, only $28 \%$ of riders reported wearing a helmet consistently and obtaining the necessary insurances and licence. This finding effectively leads to an assertion that rule-breaking and lack of proper traffic regulation aids bribery among the bodaboda riders in Kisii town.

The research also revealed another level of bribery, i.e., bribery through the intermediaries. This is what the respondents referred to as 'anonymous officers'. The officers use intermediaries to collect bribes from the bodaboda riders. This finding is consistent with past literature which showed that all the world over, intermediaries construct their careers by facilitating corrupt transactions (Ufere et al., 2012; Lambsdorff, 2013). Existing studies argue that intermediaries specialize in navigating the informal rules of corruption, which helps the citizen who works with the intermediary as well as the official they pay (Drugov, Hamman \& Serra
2014). However, it is important to understand the nature of such intermediaries and for whom they work. It would also be important to carry out further research to demonstrate why bodaboda riders continue to pay bribes through intermediaries who disadvantage them even though they are aware that those who collect bribes are intermediaries.

\section{RECOMMENDATIONS}

Arising from the findings of this study, the following recommendations seek to inform policy in addressing bribery related to bodaboda riders and county askaris.

\section{Recommendations to the National Police Service and other law enforcement agencies}

This study recommends that the National Police Service undertake intelligence led policing in gathering information and profiling of county askaris who solicit bribes from the bodaboda riders across the country. The police service and other enforcement agencies should also strictly enforce laws and regulations meant to ensure public safety on the roads like wearing of helmets, reflector jackets to ensure strict observance of traffic rules by bodaboda riders.

\section{Recommendations to the County Governments}

The county governments should formulate relevant laws and policies to govern and regulate operations of the bodaboda sector in their areas of jurisdiction. Such policies could include designating specific zones of operations for bodaboda. The county governments should then have functional mechanisms on the ground to ensure that the said laws and policies are implemented without favouritism. This effectively means that the county governments should properly screen the askaris for integrity and ethics. Moreover, the county governments should develop their own surveillance mechanisms to snub those askaris soliciting bribes from the bodaboda riders.

\section{Recommendations to Bodaboda Owners and Riders}

Bodaboda owners can help in addressing challenges in the sub-sector by ensuring that they are compliant with all the traffic regulations and requirements. This study further recommends that all bodaboda riders should acquire requisite motorcycle rider trainings, licenses, and safety gears before venturing on the roads. Law abiding individual riders also have an obligation to collaborate with security agencies and other enforcement authorities to report county askaris who solicit bribes from them.

\section{Recommendations for further research}

For further research, this present survey recommends that the finding on bribery intermediaries be taken up as an independent study. It is important to understand the nature of such intermediaries and for whom they work. It would also be important to carry out further research to explore why ordinary citizens continue to pay bribes through intermediaries even though they are aware that those who collect bribes are intermediaries. 


\section{CONCLUSION}

The present study has demonstrated the high prevalence of bribery incidences between the bodaboda riders and the Kisii county askaris in Kisii town. The thematic analysis of the responses revealed that engaging and coping with bribery is moderated, not by the respondents' demographic characteristics as age, education, marital status or gender, but by tribalism, nepotism and social interaction which defines whether a rider is considered of the inner circle or outer circle.

\section{REFERENCES}

[1] Annells, M. (1997). Grounded theory method, part I: Within the five moments of qualitative research. Nursing Inquiry, 4, 120-129. http://dx doi: 10.1111/j.1440- 1800.1997.tb00085.x

[2] Benoliel, J. Q. (1996). Grounded theory and nursing knowledge. Qualitative Health Research, 6, 406-428. http://dx doi: 10.1177/104973239600600308.

[3] Ciby, M., \& Raya, R. P. (2014). Exploring victims' experiences of workplace bullying: A Grounded Theory approach. Vikalpa: The Journal for Decision Makers, 39(2). Retrieved from http://search.ebscohost.com/login.aspx?direct=true \&db=buh\&AN $=97275615 \&$ site $=$ ehost-live

[4] Charmaz, K. (1989). Discovering chronic illness: Using grounded theory. Social Science and Medicine, 30, 1161-1172. http://dx doi:10.1016/0277-9536(90)90256-R

[5] Charmaz, K. (2006). Constructing grounded theory: A practical guide through qualitative analysis. Los Angeles, CA: Sage Publications.

[6] Chilton, R., and Pires-Yfantouda, R. (2015). Understanding adolescent type 1 diabetes self-management as an adaptive process: A Grounded Theory approach. Psychology \& Health, 30(12). https://doi.org/10.1080/08870446.2015.1062482

[7] Drugov, Mikhail, John Hamman, and Danila Serra (2014) Intermediaries in corruption: An experiment. Experimental Economics 17(1): 78-99. DOI: https://doi.org/10.1007/s10683013-9358-8

[8] Fayyaz, W., and Kamal, A. (2017). Psychosocial factors related to practicing hijab among Muslim women in Pakistan. Journal of Behavioural Sciences, 27(2). Retrieved from http://search.ebscohost.com/login.aspx?direct=true $\& \mathrm{db}=\mathrm{aph} \& \mathrm{AN}$ $=127836279 \&$ site $=$ ehost-live

[9] Feldacker, C., Pintye, J., Jacob, S., Chung, M. H., Middleton, L., Iliffe, J., and Kim, H. N. (2017). Continuing professional development for medical, nursing, and midwifery cadres in Malawi, Tanzania and South Africa: A qualitative evaluation. PLOS ONE, 12(10). https://doi.org/10.1371/journal.pone.0186074

[10] Gandomani, T. J., and Nafchi, M. Z. (2016). The essential prerequisites of agile transition and adoption: A Grounded Theory approach. Journal of Korean Society for Internet Information, 17(5). https://doi.org/10.7472/jksii.2016.17.5.173

[11] Glaser, B. (1978). Theoretical sensitivity: Advances in methodology of grounded theory. San Francisco, CA: University of California Press.

[12] Hummel, C. (2018). Bribery cartels: Collusive corruption in Bolivian street markets. Latin American Research Review, 53(2). https://doi.org/10.25222/larr.342

[13] Hussein, M. E., Hirst, S., Salyers, V., and Osuji, J. (2014). Using Grounded Theory as a method of inquiry: Advantages and disadvantages. The Qualitative Report, 19(27). Retrieved from https://nsuworks.nova.edu/tqr/vol19/iss27/3

[14] Johnson, J., and Sohi, R. (2016). Understanding and resolving major contractual breaches in buyer-seller relationships: A Grounded Theory approach. Journal of the Academy of Marketing Science, 44(2). https://doi.org/10.1007/s11747-015-0427-8

[15] Kempe Ronald Hope (2014) Kenya's corruption problem: causes and consequences, Commonwealth \& Comparative Politics, 52:4, 493-512, DOI: 10.1080/14662043.2014.955981
[16] Lambsdorff, Johann Graf (2013). Corrupt intermediaries in international business transactions: Between make, buy and reform. European Journal of Law and Economics 35(3). DOI: https://doi.org/10.1007/s10657-010-9214-7

[17] Luchidio M.T., Kahuthia-Gathu R. and Gatebe E. (2013) Impact of training boda boda operators and safety status in kakamega county, Kenya. International Journal of Advance Research. 1(9).

[18] Martin, M. W., \& Schinzinger, R. (2005). Ethics in engineering (4th ed.). New York, NY: McGraw-Hill.

[19] Matsushima, M., \& Yamada, H. (2016). Impacts of bribery in healthcare in Vietnam. Journal of Development Studies, 52(10). https://doi.org/10.1080/00220388.2015.1121241

[20] Milosavljevic, M., Noble, G., Goluza, I., Keep, A., and Ponta, G. (2015). New South Wales public-hospital dietitians and how they feel about their workplace: An explorative study using a grounded theory approach. Nutrition \& Dietetics, 72(2), 107-113. https://doi.org/10.1111/1747-0080.12119

[21] Mohd Daud, N. A., and Bond, T. (2013). Cultural values and attitudes towards guidance and counselling services in one secondary school in Malaysia: the role of a school cultural system. British Journal of Guidance \& Counselling, 41(5). https://doi.org/10.1080/03069885.2013.773957

[22] Myers, M. D. (2009). Qualitative research in business \& management. Thousand Oak, CA: Sage.

[23] Nyabwengi, Catheline Bosibori (2014). Transformation in chinkororo movement among the Abagusii of Kisii County, Kenya, 1961-2010. Masters Thesis: Kenyatta University.

[24] Pelizzo, R., Araral, E., Pak, A., \& Xun, W. (2016). Determinants of bribery: Theory and evidence from Sub-Saharan Africa. African Development Review, 28(2). https://doi.org/10.1111/14678268.12192

[25] Porter, Gina. (2014). Transport Services and Their Impact on Poverty and Growth in Rural Sub-Saharan Africa: A Review of Recent Research and Future Research Needs. Transport Reviews, 34(1), 25-45. https://doi.org/10.1080/01441647.2013.865148

[26] Remer, J. (2017). Bribery and its ethical implications for Aid workers in the developing world. Science \& Engineering Ethics, 23(1), 227-241. https://doi.org/10.1007/s11948-016-9750-9

[27] Riang'a, R. M., Nangulu, A. K., \& Broerse, J. E. W. (2017). When a woman is pregnant, her grave is open: Health beliefs concerning dietary practices among pregnant Kalenjin women in rural Uasin Gishu County, Kenya. Journal of Health, Population \& Nutrition, 36. https://doi.org/10.1186/s41043-017-0130-0

[28] Strauss, Anselm L. (1987) Qualitative Analysis for Social Scientists. Cambridge: Cambridge University Press.

[29] Transparency International (2017) The East African Bribery Index.

[30] Transparency International Kenya (2018) Traffic legislation gaps and drivers of corruption in traffic matters. Nairobi: Author.

[31] Tong, S. F., Ng, C. J., Lee, V. K. M., Lee, P. Y., Ismail, I. Z., Khoo, E. M., and Abdullah, A. (2018). Decision making process and factors contributing to research participation among general practitioners: A Grounded Theory study. PLoS ONE, 13(4), 1-17. https://doi.org/10.1371/journal.pone.0196379

[32] Ufere, Nnaoke, Sheri Perelli, Richard Boland, and Bo Carlsson (2012). Merchants of corruption: How entrepreneurs manufacture and supply bribes. World Development 40(12). DOI: https:// doi.org/10.1016/j.worlddev.2012.05.025.

[33] Van den Berg, P., \& Noorderhaven, N. (2016). A users' perspective on corruption: SMEs in the hospitality sector in Kenya. African Studies, 75(1). Retrieved from https://doi.org/10.1080/00020184.2015.1129138 on 13th January, 2019.

[34] Wallace, E. (2017). How Christian students' academic, emotional, spiritual, and social experiences impact their spiritual identity and development at a secular institution: A Grounded Theory approach. Journal of Ethnographic \& Qualitative Research, 12(1). Retrieved from http://search.ebscohost.com/login.aspx?direct=true $\& d b=a p h \& A N$ $=125989231 \&$ site $=$ ehost-live 